\title{
Isolation of infectious salmon anemia virus (ISAV) from Atlantic salmon in New Brunswick, Canada
}

\author{
D. Bouchard ${ }^{1, *}$, W. Keleher ${ }^{1, *}$, H. M. Opitz ${ }^{2}$, S. Blake ${ }^{3}$, K. C. Edwards ${ }^{4}$, B. L. Nicholson ${ }^{3}$ \\ ${ }^{1}$ Micro Technologies, Inc, 41 Main Street, Richmond, Maine 04357, USA \\ ${ }^{2}$ Animal Disease Diagnostic Laboratory, University of Maine, Orono, Maine 04469, USA \\ ${ }^{3}$ Department of Biochemistry, Microbiology and Molecular Biology, University of Maine, Orono, Maine 04469, USA \\ ${ }^{4}$ Department of Biological Sciences, University of Maine, Orono, Maine 04469, USA
}

\begin{abstract}
Infectious salmon anemia virus (ISAV) was isolated at a marine grow-out site in New Brunswick, Canada, from Atlantic salmon Salmo salar which experienced mortalities due to hemorrhagic kidney syndrome (HKS). Of 20 fish sampled in this study, 14 showed histologically various degrees of interstitial hemorrhaging, tubular epithelial degeneration and necrosis, and tubular casts in the posterior kidney, typical of HKS. Posterior kidney and spleen homogenates produced a cytopathic effect on chinook salmon embryo (CHSE-214) cells 10 to $14 \mathrm{~d}$ after inoculation. Pleomorphic virus particles in the size range 80 to $120 \mathrm{~nm}$ were seen by electron microscopy. The virus was confirmed as ISAV using reverse transcriptase-polymerase chain reaction (RT-PCR). This is a systematic diagnostic study of the isolation of ISAV on the North American continent and the first description of the growth of ISAV on the CHSE-214 cell line.
\end{abstract}

KEY WORDS: Infectious salmon anemia virus · Atlantic salmon

\section{INTRODUCTION}

Infectious salmon anemia (ISA) was first observed in Norway in 1984 (Thorud \& Djubvik 1988). The etiology of the disease was unknown for 10 yr but effective control measures were implemented based on the assumption that ISA was an infectious disease (Jarp \& Karlsen 1997). Nylund et al. (1994) confirmed that ISA virus could be transmitted with organic material after filtration through $0.2 \mu \mathrm{m}$ filters. Nylund et al. (1993) confirmed the role of sea lice in the transmission of ISA. Dannevig et al. (1995) isolated the causal virus of ISA in salmon head kidney cultures (SHK-1) and Mjaaland et al. (1997) characterized the agent as an orthomyxo-like virus. ISA has recently been reported in the United Kingdom (Rodger et al. 1998).

During summer 1996 a new disease was observed in New Brunswick, Canada, which caused severe mortal-

\footnotetext{
- Addressees for correspondence.

E-mail: microtech@wiscasset.net
}

ity in Atlantic salmon Salmo salar on some affected farms. Field observations suggested it to be caused by an infectious disease (D. MacPhee pers. comm.). Byrne et al. (1998) described the disease in Atlantic salmon as hemorrhagic kidney syndrome (HKS). Characteristic histopathological lesions included renal interstitial hemorrhage, acute tubular necrosis, and casting in the posterior kidney. Histological lesions of typical ISA, especially in the liver (Evensen et al. 1991, Speilberg 1995) were not prominent. Viral inclusions were seen in erythrocytes and unusual electron-dense inclusions were noted in the renal tubular microvilli; however, no virus was isolated in 5 cell lines, including chinook salmon embryo (CHSE-214) cells. The etiology of HKS remained unresolved in the study by Byrne et al. (1998). Collaborative efforts between Canadian and Norwegian researchers suggested that infectious salmon anemia virus (ISAV), the causative agent of ISA, might also be the cause of HKS (Mullins et al. 1998, S. Griffiths pers. comm.); however, clear evidence of an association of HKS and the ISA virus was still lacking. 
A systematic diagnostic study was conducted during an outbreak of HKS at a marine Atlantic salmon growout site in August 1997. This study included clinical, gross pathological and histopathological observations, attempts to isolate the causative agent in CHSE-214 and SHK-1 cells, and to characterize a causative agent by electron microscopy and reverse transcriptase polymerase chain reaction (RT-PCR).

\section{MATERIALS AND METHODS}

Sample collection. Twenty moribund or recently dead Atlantic salmon that had been raised for about 2 yr in marine water were collected from a site in New Brunswick, Canada, experiencing clinical mortality. Prior investigations on that site had confirmed HKS with a viral aggent as a suspected cause. Samples were collected only for virological and histological examination. Tissue samples were collected from each of the 20 fish. Posterior kidney samples from each fish were collected for histopathology and placed into 3 cups containing 10\% phosphate buffered formalin $(1: 10 \mathrm{w} / \mathrm{v})$. For virology, posterior kidney and spleen samples (approx. $1 \mathrm{~cm}^{3}$ ) were collected and placed into specimen cups containing $20 \mathrm{ml}$ of phosphate buffered saline (PBS), $\mathrm{pH} 7.1$. Tissue pieces from multiple fish were put into each cup. Two 7 -fish pools and one 6 -fish pool were collected in duplicate. All pools for virus isolation were placed on ice immediately after collection. One set of tissue pools for virological examination along with histology pools were delivered to the University of Maine, Orono, Maine, USA, where samples for virological analysis were immediately frozen. The second set of tissue pools for virological examination was transported to Micro Technologies, Inc. (Richmond, ME, USA) and held overnight at $5^{\circ} \mathrm{C}$. Results from this set of samples are discussed below.

Tissue pool processing. The 3 tissue pools were homogenized (Seward Stomacher 80) and a 1:10 (w/v) dilution was prepared in PBS pH 7.1. These homogenates were diluted to a final 1:100 (v/v) dilution in Minimum Essential Medium (MEM) with Hanks' balanced salts, 5\% fetal bovine serum (FBS), and gentamycin $\left(50 \mu \mathrm{g} \mathrm{ml}^{-1}\right), \mathrm{pH}$ 7.2. This final dilution was filtered through a $0.45 \mu \mathrm{m}$ filter to remove bacterial contamination.

Cell culture preparation. One 24-well cell culture plate of SHK-1 cells (Dannevig et al. 1997) and one 24 -well cell culture plate of CHSE-214 cells were used. SHK-1 cells were prepared in Leibovitz L-15 cell culture medium with $5 \%$ FBS, 2 -mercaptoethanol (50 mM), and gentamycin $\left(50 \mu \mathrm{g} \mathrm{ml}^{-1}\right)$. CHSE-214 cells were maintained using MEM with Earle's salts, 10\% FBS, and sodium bicarbonate as a buffering system. For viral assays, 24-well cell culture plates were prepared in MEM with Hanks' salts, 5\% FBS, and gentamycin $\left(50 \mu \mathrm{g} \mathrm{ml}^{-1}\right)$. MEM with Hanks' salts does not possess a buffering system and does not require $\mathrm{CO}_{2}$ gas to maintain proper $\mathrm{pH}$. All 24-well cell culture plates were seeded with cells to be 80 to $90 \%$ confluent after $24 \mathrm{~h}$ of incubation. All 24-well plates were covered with a pressure sensitive film (Becton Dickinson and Company) along with the plastic lid and incubated at $15^{\circ} \mathrm{C}$. The prepared 24 -well cell culture plates were inoculated with viral test samples within $48 \mathrm{~h}$ of preparation.

Viral sample inoculation. The culture medium was removed from the 24 -well cell culture plates. Six wells of each cell line were inoculated with each of the 3 viral samples. The remaining 6 wells were left uninoculated and $0.2 \mathrm{ml}$ of the appropriate cell culture medium was added. Test wells were inoculated with $0.2 \mathrm{ml}$ of diluted sample homogenates. The inoculated 24 -well cell culture plates were incubated for $1 \mathrm{~h}$ at $15^{\circ} \mathrm{C}$ for virus adsorption, after which $1 \mathrm{ml}$ of appropriate culture medium was added to each well. The plates were covered with pressure sensitive film along with the plastic lid and incubated at $15^{\circ} \mathrm{C}$.

Histology. Sections of posterior kidney fixed in $10 \%$ phosphate buffered formalin were processed and stained by hematoxylin and eosin. One tissue section (approx. 50 to $70 \mathrm{~mm}^{2}$ ) per fish was examined (Prophet et al. 1992).

Electron microscopy. Two wells of CHSE-214 cells exhibiting a cytopathic effect (CPE) were harvested for analysis by electron microscopy. Cells were harvested by scraping the cells into the medium. The cells and medium were placed in a conical microfuge tube and centrifuged at $12500 \mathrm{rpm}(15000 \times \mathrm{g}$ for $20 \mathrm{~min}$. The supernatant was decanted and the cell pellet was fixed in $3 \%$ cacodylate-buffered glutaraldehyde, post-fixed in $1 \%$ cacodylate-buffered osmium tetroxide, dehydrated in ethanol, and embedded in epoxyresin. Sections $60 \mathrm{~nm}$ thick were prepared from the embedded blocks, stained with uranylacetate and lead citrate, and viewed with a Philips CM10 electron microscope.

RT-PCR. ISAV-specific primers were designed to amplify a 493 bp cDNA sequence on genome segment 8 of ISAV. The upstream primer $15^{\prime}$ GGCTATCTACCATGAACGAATC3') previously was described by Mjaaland et al. (1997) for the Norwegian strain of ISAV. The downstream primer (5'GCGAAGTGTAAGTAGCACTCC3') was designed based on the published genomic sequence of the Norwegian strain of ISAV (Mjaaland et al. 1997, GenBank Accession no. Y10404). The extraction of RNA from ISAV infected CHSE-214 cell cultures and reverse transcription were performed as described previously (Blake et al. 1995). The PCR Super Mix (Gibco BRL no. 10572-022) con- 
tained $22 \mathrm{mM}$ Tris- $\mathrm{HCl}, \mathrm{pH} 8.4,55 \mathrm{mM} \mathrm{KCl}, 1.65 \mathrm{mM}$ $\mathrm{MgCl}_{2}$ and $220 \mu \mathrm{M}$ each dNTP, and $22 \mathrm{U}$ recombinant Taq DNA Polymerase $\mathrm{ml}^{-1}$. Forty-five $\mu \mathrm{l}$ of this Super Mix was aliquoted into a PCR tube and $0.5 \mu$ of each primer was added to give a final concentration of 50 pmol. To this, $4 \mu$ l RT-CDNA was added for a total volume of $50 \mu \mathrm{l}$, and overlaid with mineral oil. After an initial incubation for $5 \mathrm{~min}$ at $94^{\circ} \mathrm{C}, 35 \mathrm{PCR}$ cycles of $45 \mathrm{~s}$ at $94^{\circ} \mathrm{C}, 45 \mathrm{~s}$ at $59^{\circ} \mathrm{C}$, and $1 \mathrm{~min} 45 \mathrm{~s}$ at $72^{\circ} \mathrm{C}$ were performed, followed by a final elongation step for 7 min at $72^{\circ} \mathrm{C}$. The PCR amplification products compared to a DNA mass ladder were visualized by agarose gel electrophoresis and ethidium bromide stain (Gibco-BRL)

\section{RESULTS}

\section{Histology}

Four of 20 tissue sections examined showed extensive interstitial hemorrhaging affecting more than $75 \%$ of the section area. The lymphoid tissue of the renal interstitium was largely obscured by red blood cells but, when visible, seemed to be unaffected, with the exception of 1 kidney with an increase of melanomacrophages and numerous pigment particles scattered throughout the section. Interstitial hemorrhaging was visible in $20 \%$ or less of 10 kidney sections. Tubular epithelial degeneration and necrosis was present to various degrees in 14 kidney sections. Necrosis was characterized by: epithelial hypertrophy with eosinophilic staining of protoplasm; vacuolization of the epithelial cells, usually beginning from the basal membrane; widening of the intercellular spaces; pyknosis; and, in the most severe cases, complete collapse of the tubules. Several tubules contained eosinophilic casts with or without cellular debris and yellow or dark pigment (Figs. 1 \& 2). Two kidney sections had only minor hemorrhaging but extensive tubular degeneration and necrosis; however, usually kidneys with the most severe interstitial hemorrhaging had the most extensive epithelial degeneration. Two kidneys had nephrocalcinosis while in 4 kidney sections no apparent histopathological changes were visible.

\section{Virus isolation}

The 24 -well cell culture plates were monitored daily for any signs of CPE. By Day 6 post-inoculation, the SHK-1 cell monolayer, including those in the uninoculated wells, had peeled off and these cells were no longer monitored. On Day 10 post-inoculation, the CHSE-214 cells began exhibiting CPE in 1 well from 1 sample pool. From this suspect well, $0.6 \mathrm{ml}$ of super-

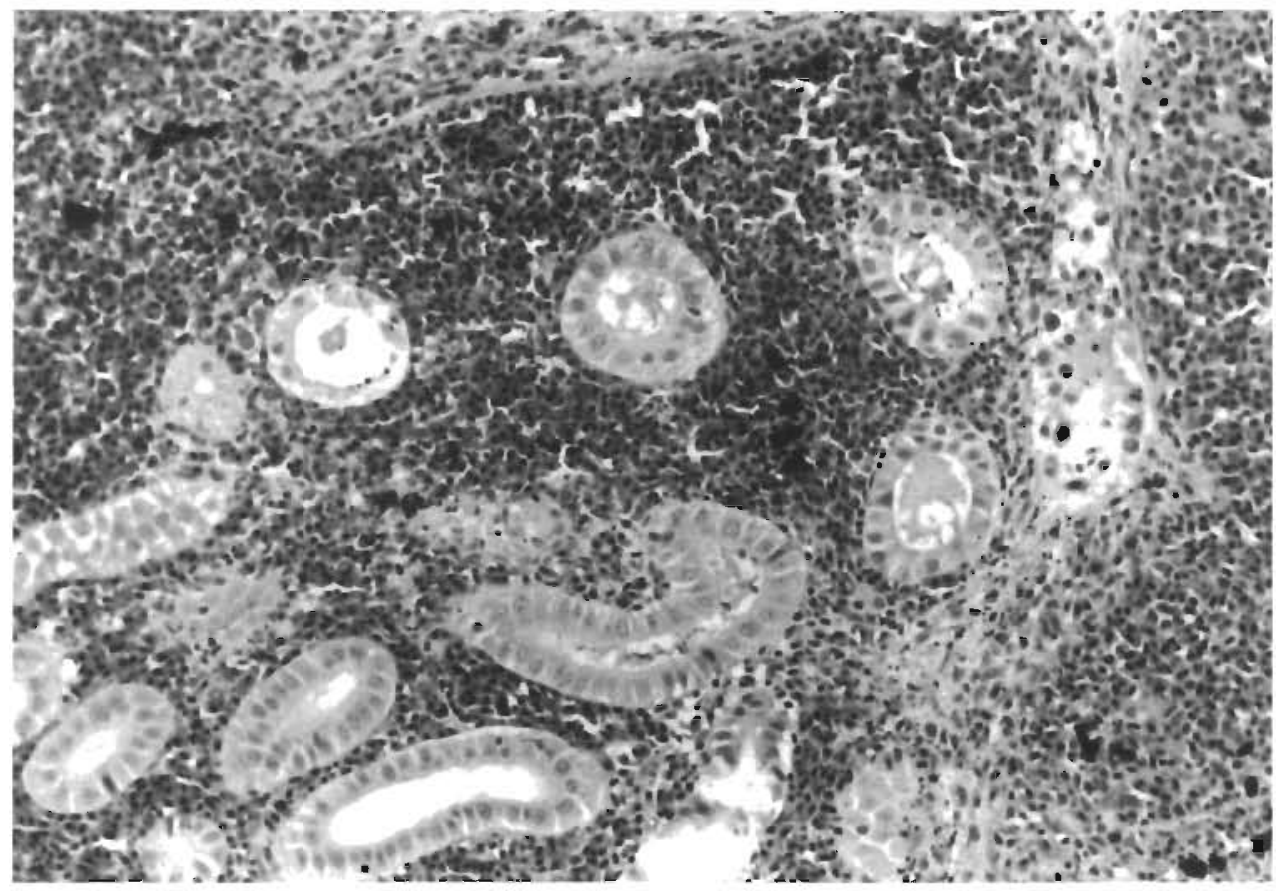

Fig. 1. Salmo salar. Kidney tissue of Atlantic salmon showing typical lesions of hemorrhagic kidney syndrome (HKS), with interstitial hemorrhaging and renal tubules at different stages of degeneration and necrosis varying from tubular epithelial swelling, necrosis of individual epithelial cells, casts in the tubular lumen to complete collapse of the tubule. 100x 


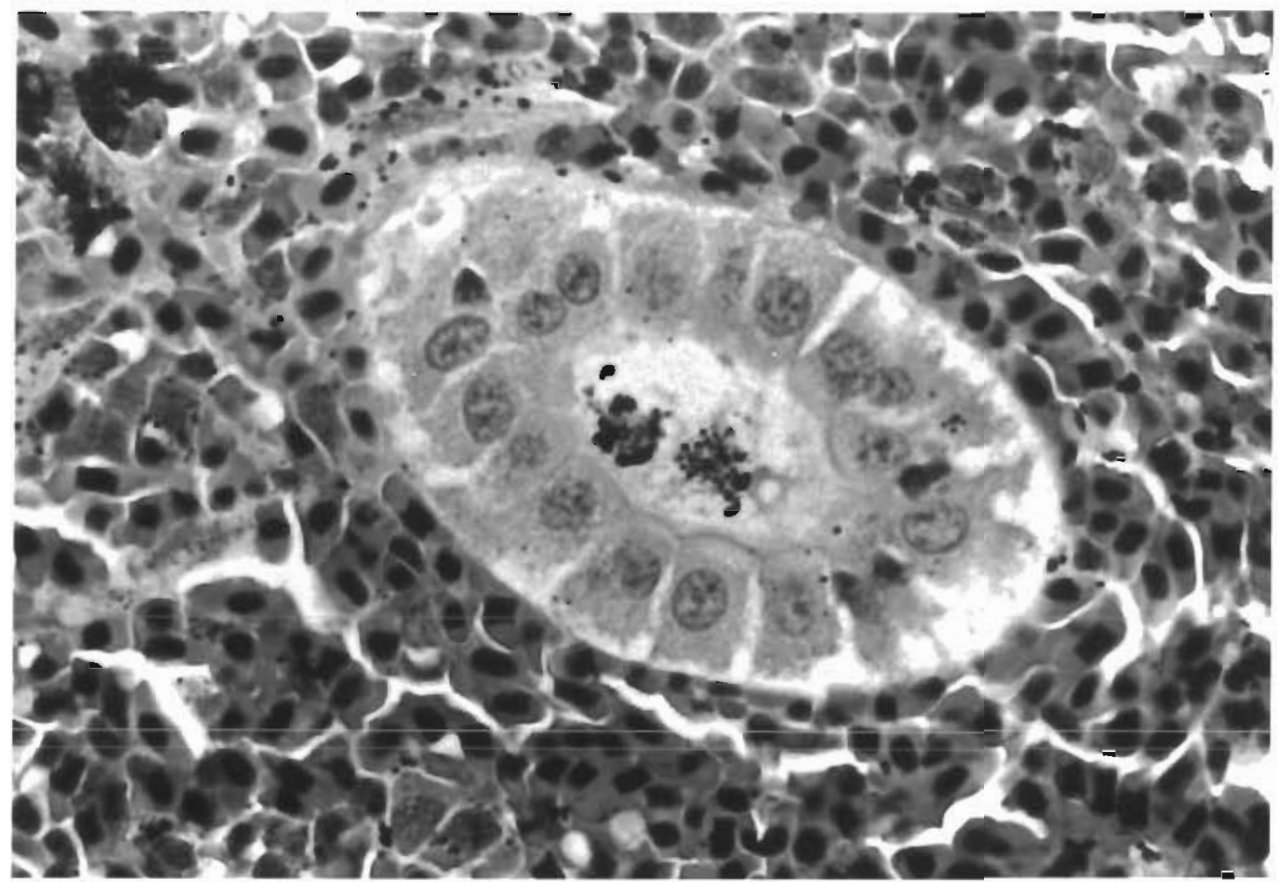

Fig. 2. Salmo salar. Renal tubule of Atlantic salmon with HKS surrounded mostly by red blood cells in the interstitial tissue and showing the early stage of tubular epithelial necrosis, epithelial detachment from the basal membrane and pigment containing amorphic cast in the tubular lumen. $400 x$

natant was removed and $0.1 \mathrm{ml}$ of this supernatant was inoculated as previously described onto 6 new wells of a 24 -well culture plate of CHSE-214 cells. On the original plate of CHSE-214 cells, CPE progressed until it was observed in all pools by Day 26 post-inoculation. Overall, 2 wells from the first sample pool, 3 wells from the second sample pool, and 1 well from the third sample pool exhibited CPE by Day 26 post-inoculation.

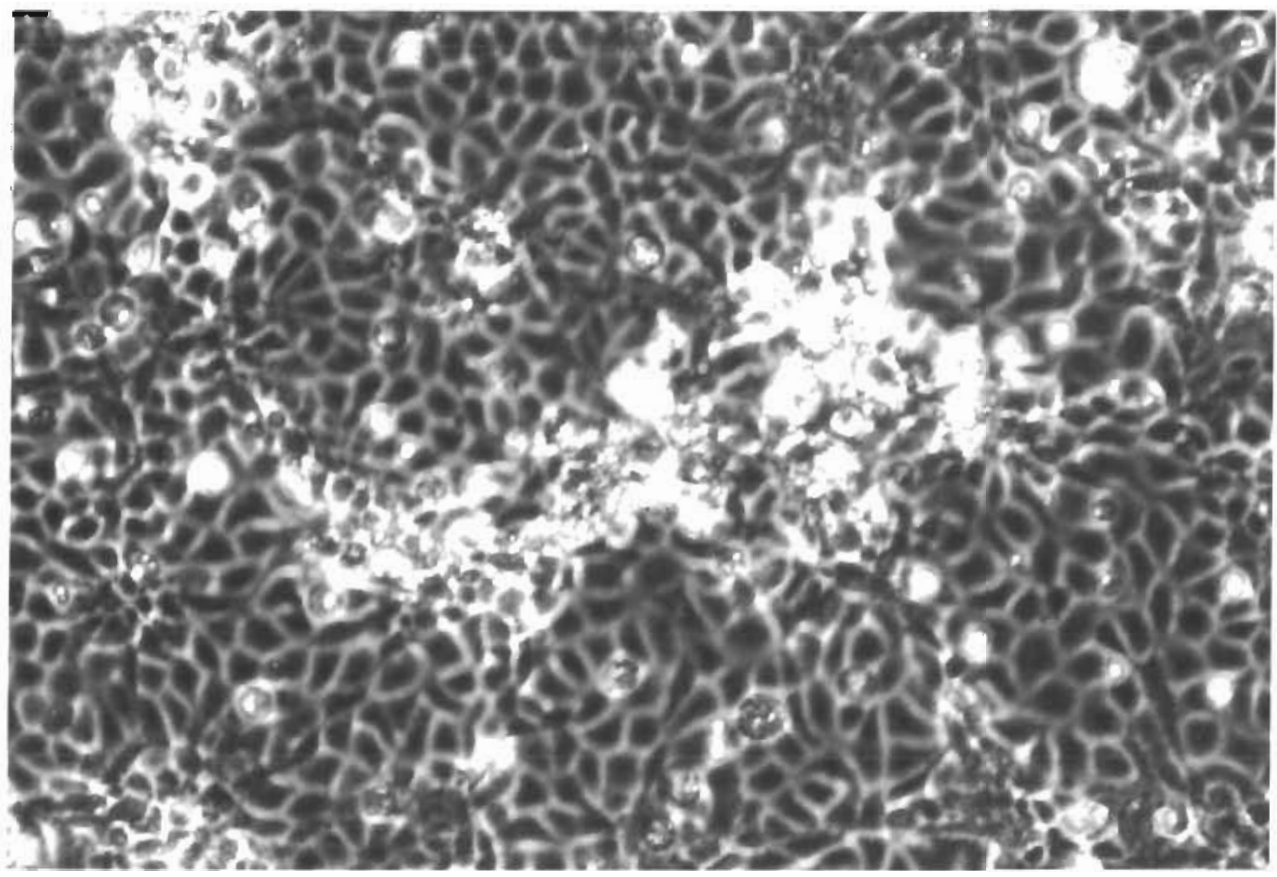

Fig. 3. Cytopathic effect produced by ISAV on CHSE-214 cells. Cell monolayer shows refractile cells and cellular necrosis 


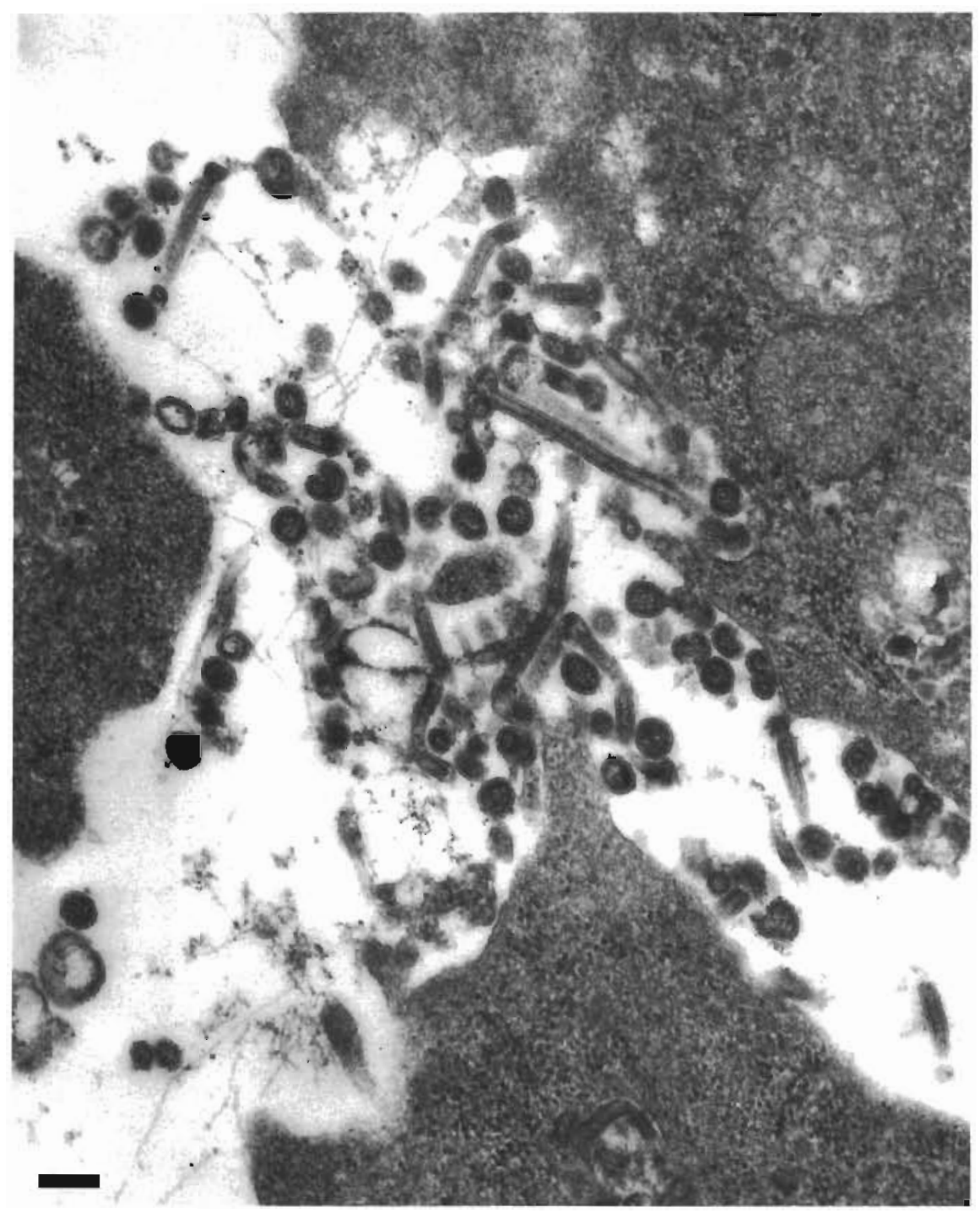

Fig. 4. Electron micrograph of thin sections of ISAV infected CHSE-214 cells. Scale bar $=150 \mathrm{~nm}$

The appearance of the identical CPE by Day 10 postinoculation of supernatant from the first suspect well onto new CHSE-214 cells demonstrated the observed CPE was the result of an infectious agent. All 6 postinoculated wells were exhibiting the initial signs of CPE. The initial signs of CPE were plaques of refractile and necrotic cells. Eventually the CPE progressed to involve $100 \%$ of the cell monolayer with only small, rounded, refractile and necrotic cells observable (Fig. 3).

\section{Electron microscopy}

Electron micrographs of infected CHSE-214 cells revealed pleomorphic virus particles in the size range of 80 to $120 \mathrm{~nm}$ (Fig. 4). An external envelope and surface projections were clearly visible. The observed virus particles were similar to those described by Dannevig et al. (1995) and were consistent with characteristics of an orthomyxovirus.

\section{Identification as ISAV by RTPCR}

RNA was extracted from CHSE-214 cells infected with the isolated virus and cDNA prepared. RT-PCR amplification of the cDNA using primers identifying a 493 target sequence on genome segment 8 of the Norwegian ISAV strain and agarose electrophoresis resulted in a RT-PCR amplification band of the expected size (Fig. 5), indicating that the amplified cDNA fragment of virus isolated from Atlantic salmon in Canada was ISAV. This was confirmed by sequencing the amplified cDNA fragment (Blake et al. 1999 - this issue). 


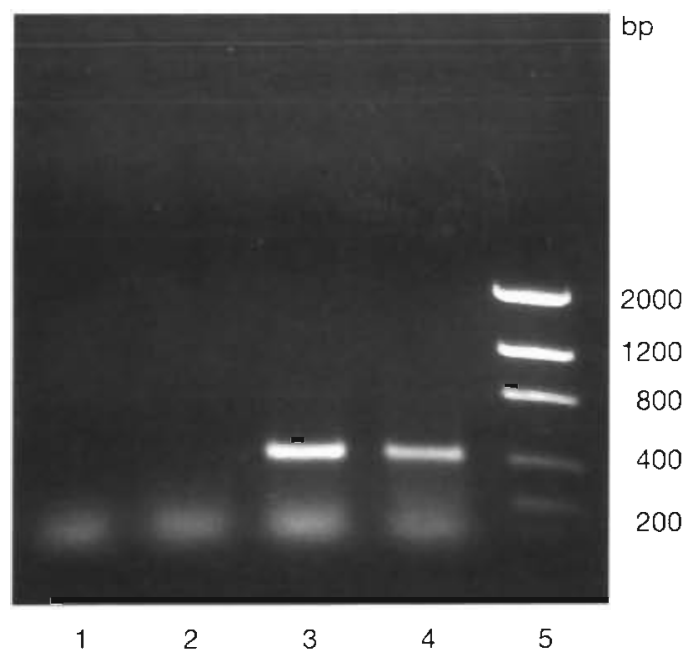

Fig. 5. Reverse transcriptase PCR products electrophoresed on ân agarose gel. Lane 1: negative PCR coniluili Lane 2: uninoculated CHSE-214 cells; Lanes 3 and 4: ISAV infected CHSE-214 cells; Lane 5: DNA mass ladder (Gibco BRL)

\section{DISCUSSION}

This systematic diagnostic study reports the isolation and identification of ISAV in North America. It is the first description of ISAV propagation in CHSE-214 cells directly from infected tissue.

Although ISAV was isolated from HKS-positive Atlantic salmon, a definite cause and effect relationship cannot be drawn. The histological lesions seen in our samples were identical to those described by Byrne et al. (1998) as HKS. No other tissue samples were collected or examined histologically; therefore, we were unable to determine whether liver lesions described for ISA by Evensen at al. (1991) and Speilberg et al. (1995) were also present. While there are gross pathological changes similar to HKS and ISA, histopathological changes within the kidney have apparently not been prominent in ISA fish in Norway.

Dannevig et al. (1995) used the SHK-1 cell line to culture ISAV. This cell line has been widely used for the cultivation of ISAV in Norway and is the only cell line recommended in the 1997 edition of the Office International Des Epizooties' Diagnostic Manual for Aquatic Animal Disease. Other cell lines, notably the Atlantic salmon (AS) and Rainbow trout gill (RtgillW1), have been shown to support growth of the virus but with no observable CPE and low infectivity titers (Falk et al. 1997). The CHSE-214 cell line has been examined for its ability to grow virus but with no success (Falk et al. 1997). Byrne et al. (1998) were also unable to isolate ISAV in CHSE-214 and 4 other cell lines. The ability in our study to observe CPE on CHSE-214 cells shows that this cell line is susceptible to this ISAV isolate. Virology practices vary widely, with many different cell culture mediums and buffers being employed. There is also a tendency to adjust the $\mathrm{pH}$ to be more alkaline. In the present study, a relatively lower $\mathrm{pH}$ (7.2) was used at the time of virus adsorption, and further decreases in $\mathrm{pH}$ were noted after adsorption. Mjaaland et al. (1997) indicated that ISAV may require a lower $\mathrm{pH}$ in order to infect SHK-1 cells. The virus has been shown to be stable at a pH as low as 5.0 in cell culture (Falk et al. 1997).

Pleomorphic virions were observed by electron microscopy in thin sections of CHSE-214 cell pellets from tissue cultures showing typical CPE. The observed virions were similar to those seen by Dannevig et al. (1995) with ISAV isolates in Norway. Molecular analysis by RT-PCR confirmed that the virus was ISAV from comparison with a published sequence (Blake et al. 1.999)

Acknowledgements. The authors thank Emily Allen and Keith Brockway for their technical assistance. This work was supported by funding through the Maine Aquaculture Innovation Center and the Maine Agricultural and Forestry Experiment Station (MAFES). MAFES publication no. 2297.

\section{LITERATURE CITED}

Blake S, Bouchard D, Keleher W, Opitz M, Nicholson BL (1999) Genomic relationships of the North American isolate of infectious salmon anemia virus (ISAV) to the Norwegian strain of ISAV. Dis Aquat Org 35:139-144

Blake S, Schill WB, McAllister P, Lee MK, Singer J, Nicholson BL (1995) Detection and identification of aquatic birnaviruses by PCR assay. J Clin Microbiol 33:835-839

Byrne PJ, MacPhee DD, Ostland VE, Johnson G, Ferguson H (1998) Haemorrhagic kidney syndrome of Atlantic salmon, Salmo salar L. J Fish Dis 21:81-91

Dannevig BH, Falk K, Namork E (1995) Isolation of the causal virus of infectious salmon anaemia (ISA) in a long-term cell line from Atlantic salmon head kidney. J Gen Virol 76:1353-1359

Dannevig BH, Brudeseth BE, Gjøen T, Rode $M$, Nergeland $\mathrm{HI}$, Evensen $\varnothing$. Press CMcL (1997) Characterisation of a longterm cell line (SHK-1) developed from the head kidney of Atlantic salmon (Salmo salar L.). Fish Shell Immunol 7 : 213-226

Evensen $\varnothing$, Thorud KE, Olsen YA (1991) A morphological study of the gross and light microscopic lesions of infectious anaemia in Atlantic salmon (Salmo salar). Res Vet Sci $51: 215-222$

Falk K, Namork E, Rimstad E, Mjaaland S, Dannevig BH (1997) Characterization of infectious salmon anemia virus, an orthomyxo-like virus isolated from Atlantic salmon (Salmo salar L.). J Virol 71:9016-9023

Jarp J, Karlsen E (1997) Infectious salmon anemia (ISA) risk factors in sea-cultured Atlantic salmon Salmo salar. Dis Aquat Org 28:79-86

Mullins JE, Groman D, Wadowska D (1998) Infectious salmon anaemia in salt water Atlantic salmon (SaImo salar L.) in New Brunswick, Canada. Bull Eur Assoc Fish Pathol $18(4): 110-114$ 
Nylund A, Wallace C, Hoveland T (1993) The possible role of Lepeophtheirus salmonis (Kroyer) in the transmission of infectious salmon anaemia. In: Boxshall G, Defaye D (eds) Pathogens of wild and farmed fish: sea lice, Vol 28. Ellis Horwood Ltd, London, p 367-373

Nylund A, Hovland T, Hodneland K, Nilsen F, Lovik P (1994) Mechanisms for transmission of infectious salmon anemia (ISA). Dis Aquat Org 19:95-100

Mjaaland S, Rimstad E, Falk K, Dannevig BH (1997) Genomic characterization of the virus causing infectious salmon anemia in Atlantic salmon (Salmo salar L.): an orthomyxolike virus in a teleost. J Virol 71:7681-7686

Prophet EB, Mills B, Arrington JB, Sobin LH (1992) Labora-

Editorial responsibility: Jo-Ann Leong,

Corvallis, Oregon, USA tory methods in histotechnology. Armed Forces Institute of Pathology, American Registry of Pathology, Washington, DC, $p 56$

Rodger HD, Turnbull T, Muir F, Millar S, Richards RH (1998) Infectious salmon anaemia (ISA) in the United Kingdom. Bul] Eur Assoc Fish Pathol 18(4):114-115

Speilberg L, Evensen O. Dannevig BH (1995) A sequential study of light and electron microscopic liver lesions of infectious anemia in Atlantic salmon (Salmo salar L.). Vet Pathol 32:466-478

Thorud $\mathrm{K}$, Djubvik $\mathrm{HO}$ (1988) Infectious anemia In Atlantic salmon (Salmo salar). Bull Eur Assoc Fish Pathol 8:109-111

Submitted: July 21, 1998; Accepted: October 28, 1998 Proofs received from author(s): January 19, 1999 


\section{Erratum}

\section{Isolation of infectious salmon anemia virus (ISAV) from Atlantic salmon} in New Brunswick, Canada

D. Bouchard, W. Keleher, H. M. Opitz, S. Blake, K. C. Edwards, B. L. Nicholson

Diseases of Aquatic Organisms 35:131-137, 1999

\section{Genomic relationships of the North American isolate of infectious salmon anemia virus (ISAV) to the Norwegian strain of ISAV}

S. Blake, D. Bouchard, W. Keleher, M. Opitz, B. L. Nicholson

Diseases of Aquatic Organisms 35:139-144, 1999

In both articles, an incorrect primer sequence appeared. The error does not change any results or conclusions.

- Page 132, under 'Materials and Methods; RT-PCR', lines $6-7$, the sentence should begin: 'The downstream primer (5'TAGGGGCATACATCTGCATC3') was designed...'.

That is, the correct primer sequence is TAGGGGCATA-

CATCTGCATC, and not the sequence published.
- Page 140 , in Table 1 , the downstream primer for NS gene should likewise be 5'TAGGGGCATACATCTGCATC3' and not the sequence published. 